\title{
THE INFLUENCE OF EXTERNAL FACTORS, CHEM- ICAL AND PHYSICAL, ON THE DEVELOPMENT OF FUNDULUS HETEROCLITUS
}

\section{BY}

\author{
CHARIES R. STOCKARD
}

With Seventefen Figures

The following experiments have been undertaken to determine to what extent the form of the embryo and its manner of development might be modified by external influences. In a previous paper ('o6), I have shown that lithium chlorid produces a definite effect on the development of Fundulus heteroclitus, as Herbst ('92) had shown for the sea-urchin and Morgan ('o3) for the frog. During the past summer I have been able to show that these abnormalities are not only definite but specific for the lithium ion in its action on this egg.

It has also become desirable, owing to recent work on the subject, to determine the permeability of the membrane of Fundulus eggs to the various salts; as well as to study the separate and combined effects of osmotic pressure and chemical actions on the development. The eggs of Fundulus, as has often been recorded, develop almost equally as well in sea-water, concentrated seawater, fresh or distilled water, and even, as Morgan ('06) has re. ently mentioned, out of water. ${ }^{1}$ Thus they furnish excellent material for a study of the actions of both hypertonic and hypotonic solutions.

The experiments were performed at Wood's Hole, Mass., while occupying a table kindly furnished me by the Vassar Brothers'

\footnotetext{
1 In regard to the development of these eggs in fresh water, Loeb ('94) states: "In fresh water the embryos hatch just as rapidly as in normal sea-water. The fish is able to live in fresh water." On the contrary, 1 have shown (Stockard, '06), that these eggs are always slower to hatch in fresh water and further that the newly hatched young soon die when left in this medium. Sumner ('o6) has also shown that the adult fish is unable to survive in perfectly fresh water.
}

The Jolrnal of Exprerimental Zcölogy, vol. iv, no. 2. 
Institute of Poughkeepsie, N. Y. I wish to express my thanks to this Institution, as well as to the authorities of the Marine Biological Laboratory, for the working facilities furnished me while there. I am also glad to express my indebtedness to Prof. T. H. Morgan for many helpful suggestions, and to Prof. A. P. Mathews for assisting me in calculating the osmotic pressures of my solutions.

\section{METHOD AND MATERIAL}

As stated above the eggs of Fundulus heteroclitus lend themselves peculiarly to such investigations as this. They are hardy and develop in different strengths of almost any solution applied. The action of a salt in sea-water solutions is generally more or less modified, owing to the presence of the salt constituents of the sea-water itself, but this effect can be controlled by the use of the distilled water solutions.

The spawning season of this fish begins at Wood's Hole about the middle of June and extends well into the first part of August, thus giving an opportunity to repeat the experiments many times and to test any uncertain points which might arise. In fertilizing the eggs I have found it advantageous to strip them from the female directly into a dry bowl and then apply the milt from the male,stirring the eggs well so as to mix them thoroughly with the milt. They are left to stand for five or ten minutes when water is added. This method insures a larger percentage of fertilized eggs than will result if they are under water when the spermatozoa are applied. In those cases where the eggs were to be treated with solutions of salts in distilled water they were placed, after being fertilized "dry" directly in fresh water, thus little if any salts could have reached the eggs after they had been removed from the body of the fish.

The time elapsing between fertilization and hatching varies considerably with the temperature, season, etc., being from about eleven to eighteen days.

The salts used in these experiments were with few exceptions fresh Kahlbaum preparations. High percentage solutions were prepared and these were diluted to the proper strengths from time 
to time as the experiments required. In discussing the experiments the percentage solutions are expressed in gram-molecular terms. The sugar solutions were prepared fresh for each experiment since they soon became acid with a fungus-like growth if kept for any length of time. Cane sugar inverts to some extent in solutions and may thus vitiate the calculations for osmotic pressures.

It was found that the amount of solution and the number of eggs in the bowl affected to a greater or less degree the rate of development. A large number of eggs in a bowl almost full of liquid develop more slowly than fewer eggs in less liquid; this is due to a difference in oxygen supply as will be shown below. In the same experiment, therefore, approximately equal numbers of eggs and equal amounts of liquid were placed in each bowl. Since there is some individual variation in the eggs from different females the experiment and control were as far as possible from the same batch of eggs.

\section{PERMEABILITY OF THE EGG MEMBRANES}

A recent paper by Brown ('05), questioning the permeability of the egg membrane of Fundulus necessitates a discussion of this subject. The solution of this question is also essential in order to properly interpret my experiments.

Loeb in 1893 showed that diffusion through the egg membrane of older embryos occurred very readily. The addition of 3 grams of $\mathrm{KCl}$ to $100 \mathrm{cc}$. of sea-water brought the heart of a Fundulus heteroclitus embryo to a standstill in a few minutes. A considerable amount of the salt must, therefore, diffuse through the egg membrane in a very short time. I repeated this experiment in the following manner: Seven five-day embryos were placed in a $0.67 \mathrm{~m}$ (about 5 per cent) solution of $\mathrm{KCl}$. Within ten minutes the heart action of one had ceased, another stopped in eleven minutes, and three others in twelve minutes. The heart's action becomes first periodic and jerky and then gradually stops, though it will ofien continue to give weak irregular contractions at intervals of one or two minutes for some time after it has apparently stopped. The embryos began to wriggle after having been in the solution only three or four minutes. When the hearts of all the individuals 
had stopped bearing, within fifteen minutes, the eggs were returned to sea-water; thirty-five minutes later one hear. " nn "nu. zting almost normally, while another was beginning feebly, the others had not recovered even after an hour. On examining the seven embryos the following morning all had entirely recovered. The result demonstrates the readiness with which salts permeate the membrane in eggs a few days old.

In 1903 Brown recorded the results of experiments, showing the immunity of Fundulus eggs and embryos to electrical stimulation. For these experiments he used eggs at various stages but some were tried when in the two-cell stage. These experiments, as Brown concluded, go to show the permeability of the membrane during the first hours of development. He states that the most probable explanation of the immunity of these eggs to electric currents as well as to osmotic changes of the medium in which they live is that the membranes of the egg are so freely permeable to ions and possibly to neutral particles that no polarization can occur. "There is a gradual increase in susceptibility to osmotic changes and to the electric current as the embryo develops, the adult being readily stimulated by the current from a single cell, which is quite without action in the embryo."

With the above results and interpretations in view, Brown ('05) has since, from far less convincing experiments, arrived at opposite conclusions. He claims now that the membrane of Fundulus eggs is practically impermeable to salts and water during the first six or eight hours of development; since eggs placed in distilled water do not lose their salts during that period. It would, be surprising if these eggs did lose their salts in distilled water as they are capable of normal development in this medium. Very probably the inorganic salts of this egg are held in combination in the protoplasm so that they are not able to diffuse out in hypotonic so!utions and the readiness with which the membrane is penetrated makes the osmotic pressure low. The fact that the conductivity of the distilled water containing the eggs increased after the first eight hours is probably due to an excretion from the eggs. They undoubtedly give off some waste products as an odor is often observed when a bowl containing eggs is uncovered after standing overnight. 
The extensive treatment of Fundulus eggs with salt solutions which Mathews ('O4) ( $^{2}$ has recorded goes to show that the egg membrane is easily permeable.

To demonstrate further the permeability of the membrane, during the first hours of development, I carried out the following experiment. Since embryos had been found to be affected in a definite manner by solutions of $\mathrm{LiCl}$ below the strength of $\frac{1}{4} \mathrm{~m}, \mathrm{I}$ determined to subject them for short periods while in the two-cell stage to strong solutions of $\mathrm{LiCl}$. Eggs were placed in a molecular and a double molecular solution of this salt in distilled water; one hour and ten minutes later they were all quite abnormal, showing the lithium effect. Some of these were then transferred to sea-water and on examination, eleven hours later, still showed the lithium abnormalities. Those left in the $\mathrm{LiCl}$ solution were all badly plasmolized or shrunken while the blastodermic cap was heaped up upon the top of the yolk, almost pinching away from it. Some eggs were removed from the double molecular solution after staying two and one-half hours in it, these failed to recover, and were in the same condition after sixteen hours as those still in the solution. Those removed from the molecular solution after one hour were in the following condition after forty hours; many were dead but some had recovered and showed the embryonic thickening forming on the egg. Of those that spent two and one-half hours in the solution one or two were still living though abnormal, the germ ring having descended only one half of the way down the yolk, and in one case an embryonic shield had formed.

Those taken from the double molecular solution after one hour were, forty hours later, almost all dead, the few living ones being very abnormal. Those that remained two and one-half hours in this solution were all dead.

\footnotetext{
2 Mathews tried with these eggs to ascertain the relation if any between the properties of the elements and their physiological action. He concluded that the poisonous action of any cation or metal upon the eggs varied inversely with the solution tension. "Thuse ions with a very low solution tension are very poisonous; those with a high tension are relatively inert. The poisonous action of any anion also follows this rule." Further "there is an inverse relationship between atomic volume and poisonous action; and a direct relationship between equivalent weights and poisonous action. Poisonous action of the metals is a periodic function of their atomic weights. Elements which have a low atomic volume and high equivalent weight, as mercury, are more active than those with a high atomic volume and a low equivalent weight, as sodium." Many exceptions to the foregoing were found.
} 
After seventy hours those that spent one hour in the molecular solution produced some living embryos, and though well formed they were slower than the control in their rate of development. Those that remained in this solution for two hours showed only a few living eggs with badly stunted embryos. Of those from the double molecular solution of $\mathrm{LiCl}$, after one hour, only one in twenty was alive, and this one was stunted.

Solutions of double molecular and one and one-half molecular strengths were prepared with sea-water and an experiment similar to the above was conducted with like results, although the eggs recovered somewhat more readily after being removed from these solutions and returned to pure sea-water. This latter fact may indicate that some of the salts of the sea-water tend to counteract in part the effects of the $\mathrm{LiCl}$.

At first sight the above results seem to contradict my former statement to the effect that eggs removed from $\mathrm{Li}$ solutions in three, four or five hours showed no toxic effects in their later development. It is recalled, however, that the solutions then used were weak ones, while the above are strong enough to kill all eggs remaining in them.

Such results as these can leave, I think, no doubt as to the fact that the membrane of Fundulus heteroclitus eggs is readily permeable to salts during the first few hours of their development. The permeability of this membrane at later stages is also beyond question, and probably it becomes more readily permeable as development advances.

THE DEVELOPMENT OF FUNDULUS EGGS OUT OF WATER

The only reference hitherto made to the development of Fundulus eggs out of water is that by Morgan ('o6), to the effect that these eggs will develop on a glass plate in a moist atmosphere. I undertook to rear embryos in this fashion to ascertain what abnormalities, if any, would result from such treatment. The most interesting result obtained was that although these fish develop to all appearances in a perfectly normal manner, except at a little faster rate, they are entirely unable to hatch while on the moist plates. Eggs were kept from June 30 until August 2 in a 
healthy condition without the embryos breaking through the membranes. Thus these fish remained enclosed in their egg membrane for thirty-three days while the control had begun to hatch after thirteen days.

As there are some points of interest to be brought out in connection with the details of this experiment it may be briefly described. Eggs were placed, shortly after fertilization, on moist glass with all superfluous water removed, they were arranged so as not to be in contact with one another and then covered with a finger bowl to prevent the evaporation of the surrounding moisture. Other eggs were arranged in a similar manner when in the two-cell stage, while still others at this period were covered by finger bowls which had moist filter paper closely pressed in them, thus insuring a more moist atmosphere about the eggs.

When the eggs were fifty-three hours old the control in seawater showed embryos distinctly formed with the blastopores closed, those on the moist glass also had their blastopores closed and were slightly in advance of the control in their development. One of the eggs that had become dried and shrunken also showed a normal embryo. At three, four, six and ten days old the ones, on the moist glass were continuing to develop normally though at a faster rate than the control. This more rapid development was in all probability due to the better aëration out of water.

When fourteen days old many of the control had hatched. At this time those that were under finger bowls without moist paper had become so dry, although moisture had been added several times, that a number of them died; in one lot fifty-four were dead and only twenty still alive, while another lot had forty-seven living and thirty-four dead. This and other such cases indicate that it is important to keep the eggs moist. The ones supplied with moist filter paper were all alive. None of these eggs out of water had hatched; twenty-three were then taken from the glass plate and put into a finger bowl containing sea-water. Eleven hatched; in five minutes, eighteen were out after ten minutes and the entire lot, twenty-three, were swimming about after being in the sea-water for only eighteen minutes. These fish after hatching seemed further developed than the controls which had also hatched, evi- 
dently they had been prevented from hatching owing to their inability to break through the egg membrane when out of water.

On the fifteenth day none on the moist glasses had hatched, with the exception of two which I feel sure came out on account of too much moisture or water having been put about those that were rather dry on the day previous. Thirty eggs were now put into sea-water, three of which hatched after ten minutes, thirteen were out in fifteen minutes, twenty-five in twenty minutes, while twentyseven of the thirty eggs had hatched within twenty-five minutes. On hatching, the embryos swim directly to the top of the water and to the side of the bowl nearest the brighest light thus showing a negatively geotropic and a positively heliotropic reaction.

At sixteen days old not an egg on the moist glasses had hatched, with the exception of the two which had hatched three days before. Twenty eggs were now placed in sea-water, the first one came out after ten minutes. It seems as a rule to require about ten minutes for the eggs to begin hatching and after this period they come out very rapidly. Fifteen were out after fifteen minutes and all were hatched after being in the water only twenty-seven minutes. On the morning of the seventeenth day two of those on the moist glass had hatched, but again an extra amount of moisture had been put about the eggs on the previous day.

When twenty days old, six days after hatching had begun, all of the controls were hatched, those on the moist glasses were alive and well, though none had hatched. An excess of moisture was added to them while still on the glass and twelve embryos came out within twenty minutes, the moisture was then drawn off and hatching ceased.

When twenty-six days old a few of the eggs began to die, three or four out of fifty died on one glass. This was probably due to want of food as at this time all of the yolk had been absorbed for several days past as seen by comparing Fig. I of a newly hatched control embryo twelve days old, with Fig. 2 of a moist glass embryo hatched when eighteen days old ( $y k$ the yolk mass). A comparison of these two figures will also show how the embryos on the moist plates have continued to grow and develop within the egg membrane. When eighteen days old one of these was equally as large 
as an eighteen day control embryo which had been free swimming for four or five days.

When twenty-seven days old, more embryos were dying, but those put into sea-water began to hatch within ten minutes, though they swam abnormally at first, going in a circular or spiral course. This was due to the fact that the fish had become cramped by its twisted position within the egg membrane and for an hour or so after hatching they were unable to straighten themselves, but they finally do so and their movements become normal. When at rest the crooked ones have a tendency to topple over on one side.
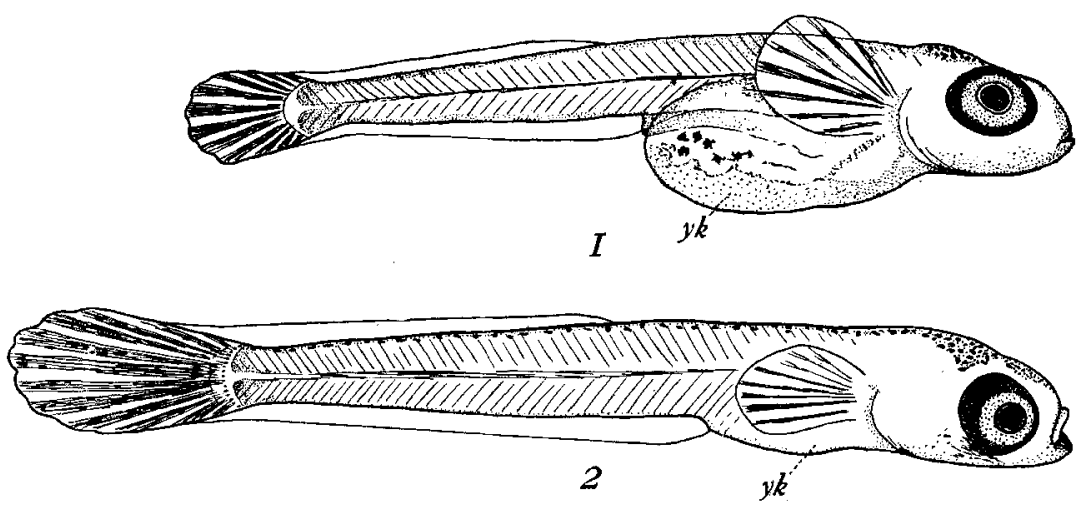

Fig. I. A normal embryo just hatched, twelve days after fertilization. $y k$, yolk mass. $\times 17$ diameters.

Fig. 2 A newly hatched embryo which was developed out of water and made to hatch by being placed in sea-warer when eighteen days old. $y k$, yolk mass. $\times 17$ diameters.

After thirty-one days they were still well and unhatched on the glass although a few had starved to death each day. When thirtytwo days old, five were placed in sea-water, three came out within twelve minutes and all were out in twenty-three minutes after being put into the water. These had their bodies bent owing to the long cramped position they occupied within the egg membrane, though all soon straightened out and swam normally. 
THE OSMOTIC EFECTS RESULTING FROM DEVELOPMENT IN SUGAR SOLUTIONS

In order to be able to discriminate between the osmotic effects and the effects of salt solutions it was necessary to make a careful study of the manner in which the eggs reacted to the physical changes; i.e., to the osmotic pressures of the solutions. Loeb ('94) had found that these eggs are "remarkably independent of the concentration of the sea-water." He found that the embryos develop in a perfectly normal fashion in fresh water as well as sea-water to which five grams of $\mathrm{NaCl}$ had been added to each Ioo cc. of water. When seven and one-half grams of $\mathrm{NaCl}$ were added to each $100 \mathrm{cc}$. of sea-water a blastoderm was still formed, but rarely an embryo. When twenty grams of $\mathrm{NaCl}$ were added to Ioo cc. of sea-water the power of development of freshly fertilized eggs was annihilated within three or four hours. The only abnormalities that Loeb observed when eggs were in concentrated seawater were a shrinking of the yolks and a slower rate of development. These experiments fail to show whether the effect is osmotic or chemical, since by using $\mathrm{NaCl}$ one is dealing with a chemical poison as well as increasing the osmotic pressure of the solution.

I have used sugar solutions prepared both in fresh and seawater to determine the effects of osmotic pressure on these eggs. The sugar itself is supposed to exert slight if any chemical action.

The eggs of Fundulus, since they develop normally in fresh water, as recorded by Loeb ('02), Mathews ('04), the writer ('06), and others, are evidently insensitive to the lowering of the osmotic pressure of their surrounding medium. This is due probably in part to the inorganic salts of this egg being held firmly in combination with its colloidal organic compounds in the protoplasm.

Seven independent experiments were carried out with sugar solutions in distilled water of the following strengths: $1.53 \mathrm{~m}$, $1.33 \mathrm{~m}, 1.0 \mathrm{~m}, 0.66 \mathrm{~m}, 0.5 \mathrm{~m}, 0.33 \mathrm{~m}$, and $0.16 \frac{2}{3} \mathrm{~m}$. Solutions of sugar in sea-water were used of the strengths $1.33 \mathrm{~m}, 1.0 \mathrm{~m}, 0.88 \mathrm{~m}$, $0.66 \mathrm{~m}, 0.5 \mathrm{~m}, 0.33 \mathrm{~m}$, and $0.16 \mathrm{~m}$. A molecular solution of sugar is equivalent to about a 31.4 per cent solution and exerts an 
osmotic pressure of 22.4 atmospheres. The osmotic pressure of the sea-water at Wood's Hole, as determined by Garrey ('05) is 2r.9I8 atmospheres, thus being nearly equivalent to a gram molecular solution of sugar.

\section{DISTILLED WATER SOLUTIONS OF SUGAR}

Several of the sugar solutions employed exert an osmotic pressure lower than that of sea-water, yet owing to their high specific gravity the eggs float on them. We may first consider only the effects induced by the $1.53 \mathrm{~m}, \mathrm{I} .33 \mathrm{~m}$ and the $1.0 \mathrm{~m}$ solutions. Two hours after being in the $1.53 \mathrm{~m}$ and the $1.33 \mathrm{~m}$ solutions the yolks, have shrunken in a peculiar way, being circular in outline when viewed from above and oval when seen from the side, having such a form as a plastic sphere would assume if pressed between two horizontal planes. In the molecular solution the yolk does not show this effect to any considerable degree and the rate of development is slightly ahead of the control. After about twenty-three hours all of the eggs in the $1.53 \mathrm{~m}$ sugar solution are dead, the membranes of many have burst and allowed the yolk to stream out, while in others the yolk is a small contracted and concentrated mass. At this time many eggs in the $1.33 \mathrm{~m}$ are also dead, although the few still alive are further advanced than the control, the blastoderm lies flat on the yolk and the germ-ring is further down. Those twenty-three hours old in the molecular solution are alive and the germ-ring is further over the yolk than in the control. The osmotic pressure of the molecular solution should be about 22 atmospheres which is almost equivalent to the pressure of sea-water, that of the $\mathrm{r} .33 \mathrm{~m}$ is 26.2 atmospheres, only four atmospheres higher; while the $1.53 \mathrm{~m}$ has a pressure of 34.278 atmospheres or about twelve atmospheres above the pressure of seawater. Eggs in the latter solution are seen to be fatally affected within twenty-four hours. We meet here with the same peculiar problem that I find in looking over Madame Rondeau-Luzeau ('O2) and Morgan's ('o6) results. They found the upper limit of $\mathrm{NaCl}$ on frogs' eggs to be about 2 per cent, which exerts a pressure of I $_{3} .6 \mathrm{r}$ atmospheres, while Morgan found the upper limit for cane sugar to be 12 per cent, with a pressure of 8.376 atmospheres. I have found 
as shown below that Fundulus embryos develop in a $\frac{1}{3} \mathrm{~m}$ solution of $\mathrm{MgCl}_{2}$ in sea-water. Here we have a pressure of about thirteen atmospheres above that of sea-water, while as indicated above a pressure of twelve atmospheres more than sea-water is fatal within twenty-four hours when exerted by a cane sugar solution. A possible explanation of such results is that some of the cane sugar becomes inverted and, therefore, exerts a pressure greater than that estimated, since two molecules are now present for each one calculated. The difference in activity which Jenkinson ('o6) has lately recorded between isotonic solutions of cane sugar and dextrose on the frog's egg may also be due to the cane sugar having become partially inverted and, therefore, his solutions may not have been isotonic, as he thought; at least this explanation seems just as probable as the one he advances, that the membranes differ in their permeability to the two sugars. ${ }^{3}$

The augmentation of the effect when salts are added to sugar solutions that Morgan ('o6) has recorded for the frog and as I shall show below for the fish egg may be largely due to the increased pressure or to the peculiar injurious effect caused by some action of the cane sugar. The sugar used in most of my experiments was crystallized "rock-candy," and was probably pure.

In those solutions of sugar which exert a pressure lower than that of the sea-water the embryos develop normally and often at a rate faster than that of the control. This acceleration probably is due to their floating and hence being better aerrated. Another point of interest regarding eggs in these solutions is that the yolks often become swollen as would be expected in hypotonic solutions. This observation has never been recorded for these eggs in fresh water nor in any distilled water salt-solutions which were hypotonic to sea water. I have treated them with numbers of such solutions, always making careful study of the structural or form changes which resulted, but in no case have I observed a swelling of the yolk except in some, not all, of these hypotonic sugar solutions. This swelling may be due to the sugar becoming inverted

\footnotetext{
${ }^{3}$ This spring I have had an opportunity to compare the action of cane sugar with simple sugars, such as glucose and levulose, on the frog's egg, and find that the effects of the cane sugar can be explained without assuming any inversion to take place.
} 
after penetrating the membrane. If such should occur, the concentration of the sugar solution within the membrane would be higher than that without and this might produce a strong endosmosis which would result in the swelling of the yolk. The fact that the yolk or egg does not swell in fresh water or in hypotonic solutions has been used as an argument to show that they are immune to osmotic effects. That they are not, however, entirely immune to such effects has been shown above.

\section{THE SEA-WATER SOLUTIONS OF SUGAR}

The yolks shrink in these solutions in the manner mentioned above, often within one hour after having been put into the solution. The shrinkage of the yolk occurs so promptly that the outer membrane fits loosely around the egg, and often shows an indentation on one side. There occurs below the blastoderm in many cases a bubble-like appearance which disappears, however, as development progresses. When about forty hours old many eggs die in the $\mathrm{r} .33 \mathrm{~m}$ solution, which exerts a pressure of about twenty-six atmospheres more than ordinary sea-water. The dead eggs usually have a polar ball of protoplasm on the shrunken yolk. The living embryos have the tail end indistinctly indicated and the blastopore remains open much longer than is usually the case. If eggs were removed from these solutions and put into sea-water at any time before twenty hours they soon recovered and developed normally with the exception of those from the stronger solutions, in which case the yolk rarely recovered its full size, and in consequence the pericardium seemed abnormally large. As development continues in the stronger solutions, the yolks become smaller and smaller, and the embryos are likewise much dwarfed with very weak heart contractions which begin only some time after the control embryos have etsablished a free circulation. Fig. 3 shows many of these characters in an embryo when five days old in a molecular solution of sugar in sea-water. Fig. 4 shows the condition of a control embryo of the same age. The body of the embryo is often abnormally bent or twisted on the yolk. The sluggish circulation at times allows the blood to accumulate in certain vessels, commonly in the veins along the ventral line of the tail, as large 
red spots. When thirteen or fourteen days old the embryos in the I.33 m sugar solution resemble the normal embryos of only four or five days. The eggs returned to sea-water after being twenty hours in this solution begin hatching when fourteen days old. Only in the $0.16 \frac{2}{3} \mathrm{~m}$ solution of sugar in sea-water were the embryos observed to hatch. The little fish seemed almost normal although they swam peculiarly as their yolks seemed too large and heavy for them to carry.
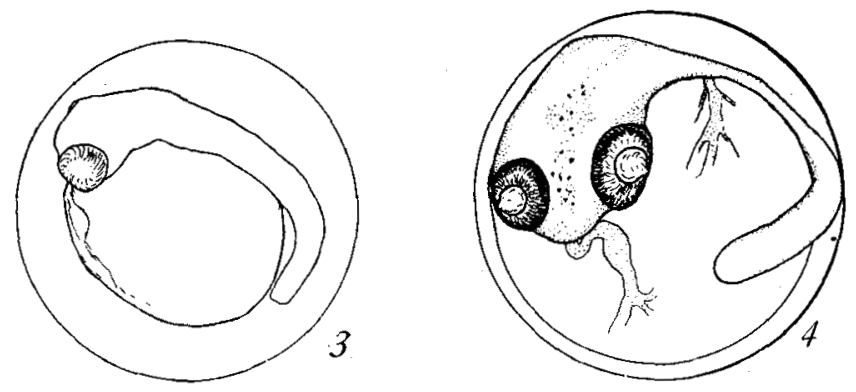

Fig. 3 An embryo from a $0.88 \mathrm{~m}$ ( 30 per cent) sea-water sugar solution five days after fertilization, showing the greatly contracted jolk and the dwarfed condition. $\times 17^{\frac{1}{4}}$ diameters.

Fig. 4 A normal control embryo of the same age. $\times 17 \frac{1}{4}$ diarneters.

The above effects are those expected to result from an increased osmotic pressure, and they go to show that although these eggs are without doubt very resistant to such pressure, it nevertheless exerts an influence on their development. It will be noted by comparing the effects of the sugar solutions in distilled water with those in seawater that a pressure more than double as strong in sea-water produces a much less injurious effect on the eggs. A not impossible explanation of this peculiar fact is that sugar in the fresh water solutions becomes inverted much more readily than in sea-water. ${ }^{4}$ The fresh water solutions of sugar were found to show an acid reaction within a day or two after their preparation, and this acid condition would cause the inversion of the cane sugar. On the

'Dr. S. P. Bebee, of the Cornell University Medical Collegc, has analyzed sugar solutions for me with the following results: A 15 per cent distilled water solution of cane sugar becomes partly inverted if allowed to stand for a day or so in the laboratory, while a ${ }_{5}$ per cent sea-water solution kept under similar conditions showed no trace of inversion after three days. 
other hand sea-water is neutral and the sugar would be much less disposed to invert under such a condition. A fungus-like growth often attacks eggs in fresh water, while I have never observed any such growth about eggs that were immersed in sea-water. The fungus grows in a slightly acid medium and is often present in fresh water solutions of sugar. The acid condition of a solution is in itself injurious. Owing to these conditions a frequent change of the sugar solutions was necessary.

Solutions of glucose and glycerine were also used to test osmotic effects but these chemicals proved to be impure.

\section{THE SPECIFIC CHARACTER OF THE LITHIUM EMBRYO}

In my paper on the devlopment of Fundulus in solutions of $\mathrm{LiCl}$, it was only possible to state at that time that lithium induced certain definite effects which were characteristic of this salt's action. It was also suggested that these effects might be specific for lithium but such could only be known after a number of other lithium salts, as well as a number of the salts of other metals had been used. I have since employed many other metallic salts and have found none of them'to produce with any constancy the abnormalities in development which result from the use of lithium salts. ${ }^{5}$

An experiment was first carried out in which eggs were subjected to solutions of $\mathrm{LiNO}_{3}$ and $\mathrm{Li}_{2} \mathrm{SO}_{3}$ to ascertain whether the resulting development would be similar to that found in $\mathrm{LiCl}$ solutions.

Eggs were placed soon after fertilization in distilled water solutions of $\mathrm{LiNO}_{3} \frac{1}{9} \mathrm{~m}$ and $\frac{1}{28} \mathrm{~m}$, and $\mathrm{Li}_{2} \mathrm{SO}_{4} \frac{1}{13} \mathrm{~m}$ and $\frac{1}{50} \mathrm{~m}$. The first four or five hours of development was almost normal, but after eight hours those in $\mathrm{LiNO}_{3} \frac{1}{2} 8 \mathrm{~m}$ were beginning to send a projection of the periblast down into the yolk substance, a continuation of this process results in the large bubble-like segmentation cavity before described ('06). When twenty-two hours old the germ-ring is just below the equator in the control (Fig. 9). Those

\footnotetext{
${ }^{5}$ Madame Rondeau-Luzeau ('o2) and Morgan ('o6) have found that the upper limit of LiCl that the frog embryo can stand is a 0.65 per cent solution, the osmotic pressure of which is 5.161 atmospheres, while the upper limit of $\mathrm{NaCl}$ is about 2 per cent and exerts a pressure of 13.61 atmospheres which is more than double that of the lithium solution. This comparison shows that the effects of the lithium salt are not due to its osmotic pressure alone.
} 
in $\mathrm{LiNO}_{3} \frac{1}{9} \mathrm{~m}$ a few show the blastoderm as a polar ball with large bubble-like segmentation cavity (Fig. 5). Many eggs, however, have polar caps with peripheral germ-rings and a small embryonic shield just beginning to form (Fig. 6). A very few are more nearly normal with the germ-ring extending one-third over the yolk sphere. This is the same condition found in eggs of this age in solutions of $\mathrm{LiCl}$, which gives for the first few hours no evident effect, then retards the development, preventing the downgrowth of the germ-ring, and often causing the formation of polar protoplasmic balls with the bubbles beneath, shown in Figs. I, 2, 3 and 4 in my earlier paper ('o6). It might be objected that at this stage of development there are only a limited number of ways that the eggs could be affe:ted. This may be granted, but from what is recorded in other sections of this article it will be seen that there are several possible modifications that may appear, and no other substances have given, with any degree of constancy, the above modifications. Those in the $\frac{1}{28} \mathrm{~m} \mathrm{LiNO}_{3}$ solutions were in a similar condition.

After twenty-three hours in $\mathrm{Li}_{2} \mathrm{SO}_{4} \frac{1}{13} \mathrm{~m}$ most of the eggs are dead with polar balls of protoplasm. Of those still alive, most have polar caps with bubbles beneath (Fig. 7). Others have polar caps with peripheral germ rings and embryonic shields just forming (Fig. 8); a very few are more nearly normal and show the germ-ring one-fourth the way down the yolk. $\mathrm{Li}_{2} \mathrm{SO}_{4} \frac{1}{50} \mathrm{~m}$ has caused similar though less pronounced effects.

The control eggs when forty-six hours old show the embryos distinctly marked out with optic vesicles and lenses visible. In the $\mathrm{LiNO}_{3} \frac{\dot{2}}{\mathrm{~g}} \mathrm{~m}$ at this time a few eggs are dead with polar caps; their blastoderms showing a bubble-like appearance beneath. Many have embryonic thickenings forming in the polar caps similar to the condition shown in my former Fig. I8. A few have their caps extending halfway over the yolk with short embryos formed, a few others have the blastopores almost closed although the head end of the embryo is abnormal. In $\mathrm{LiNO}_{3} \frac{1}{28} \mathrm{~m}$ many eggs are dead, a few have their blastopores closed though the head end of the embryo is abnormal with no eyes showing. There are others with the blastoderms only one-half over the yolk and form- 
ing short embryos. In $\mathrm{Li}_{2} \mathrm{SO}_{4} \frac{1}{13} \mathrm{~m}$ some are dead, others have a polar cap with an embryo forming in it. Of those in $\mathrm{Li}_{2} \mathrm{SO}_{4} \frac{1}{50} \mathrm{~m}$ some are dead, others are with the blastopore almost closed, but the embryos show no optic vesicles as yet, a few have polar caps with embryonic thickenings in them.

When seventy-two hours old, the eggs in $\mathrm{LiNO}_{3} \frac{1}{9} \mathrm{~m}$ have some embryos almost as long as those of the control but with no circula-
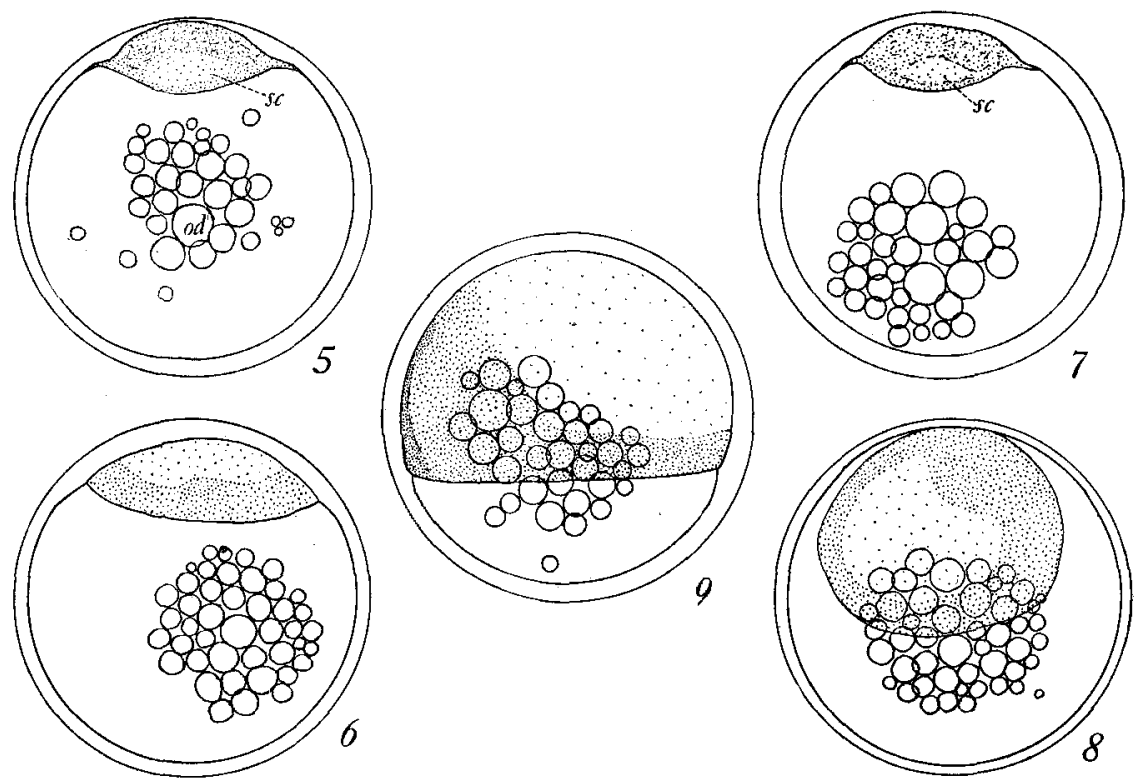

Fig. 5 An egg from a $\frac{1}{9} \mathrm{~m} \mathrm{LiNO}_{8}$ solution twenty-three hours after fertilization. sc, segmentation cavity; od, oil drops.

Fig. 6 From a $\frac{1}{38} \mathrm{~m} \mathrm{LiNO}_{3}$ solution when twenty-three and one-half hours old.

Fig. 7 From a $\frac{1}{5} 0 \mathrm{~m} \mathrm{Li}_{2} \mathrm{SO}_{4}$ solution at twenty-three hours old $s c$, segmentation cavity.

Fig. 8 From a $\frac{1}{13} \mathrm{~m} \mathrm{Li}_{2} \mathrm{SO}_{4}$ solution at twenty-three and one-half hours old.

Fig. 9 A control egg of twenty-three hours. All magnified $17 \frac{1}{4}$ dia.

tion apparent; the heads are poorly formed and show no optic vesicles in surface view. In the $\mathrm{LiNO}_{2} \frac{1}{28} \mathrm{~m}$ solutions all of the eggs are dead. In $\mathrm{Li}_{2} \mathrm{SO}_{4} \frac{1}{13} \mathrm{~m}$ some have the germ-rings only one-half way over the yolk, with short embryos formed; in others development has stopped. In the $\mathrm{Li}_{2} \mathrm{SO}_{4} \frac{1}{50} \mathrm{~m}$ solution most of the eggs are dead though a few have badly twisted embryos with poorly formed heads and no optic vesicles. 
At ninety-six hours old, the $\mathrm{LiNO}_{3} \frac{1}{9} \mathrm{~m}$ embryos show no eyes, the circulation of the blood can not be detected, while in the control it is very distinct. The pigment spots are scarce. The $\mathrm{Li}_{2} \mathrm{SO}_{4} \frac{1}{13} \mathrm{~m}$ eggs have short embryos with their blastopores still open.

When eight days old, those eggs in $\mathrm{LiNO}_{3} \frac{1}{9} \mathrm{~m}$ have short embryos with poorly formed eyes, they are pale in appearance, the heart beats slow the blood is colorless, and the tail unusually bent. Comparing this general description with the detailed one recorded for the development of this fish in solutions of $\mathrm{LiCl}$ it will be found that the development of the egg of Fundulus is as characteristic in solutions of lithium salts as is that of the frog under like conditions as recorded by Gurwitsch ('95, '96), Morgan ('03, 'o6) and others.

\section{THE EFECTS OF METALLIC CHLORIDS ON THE DEVELOPMENT OF FUNDULUS EGGS}

A number of chemical solutions have been employed singly and mixed in order to further analyze osmotic and chemical action, as well as to distinguish if possible any definite morphological response that might result from the action of any one salt. The notes on these experiments have become so voluminous that it is inadvisable to attempt to record them all. I shall, therefore, state as concisely as possible the factors involved and the chief results that followed.

Loeb's ('93) experiments with $\mathrm{KCl}$ were repeated :" the concentrations of the solutions used being $\frac{1}{2} \mathrm{~m}, \frac{3}{8} \mathrm{~m}$ and $\frac{5}{8} \mathrm{~m}$ in distilled water and $\frac{1}{2} \mathrm{~m}, \frac{3}{4} \mathrm{~m}$, and molecular in sea-water. Many of the eggs in the stronger solutions died during their early development.

\footnotetext{
${ }^{B}$ Loeb observed the interesting fact that Fundulus embryos would develop in solutions of $\mathrm{KCl}$ without circulation of the blood taking place. The heart was entirely still and the blood failed in consequence to move through the vessels. He stated that in these cases the blood system developed normally, the only peculiar point being that the pigment spots did not migrate to the blood vessels and arrange themselves along them as they usually do. I find that the circulatory system does develop to some extent but by no means normally as may be seen by a casual examination of the heart. Hence possibly the failure of the pigment cells to migrate. Loeb also found that embryos four to six days old were killed by remaining one hour in a 1.5 per cent solution of $\mathrm{KCl}$ as a result of the effect of this salt upon their heart's action, while if put into a 5 per cent solution after fertilization they live and develop.
} 


\section{The Influence of External Factors on Development 183}

Solutions of $\mathrm{KCl}$ in distilled or sea-water caused the eggs to develop at a slow rate, the yolks were shrunken and bubble-like appearances were often seen below the embryonic shield. When studied in section these eggs showed the following conditions: The periblast beneath the embryonic shield had become vacuolated with huge cavities in it as shown in Fig. 10. It thus bulged into the yolk mass and the cavities produce the bubble-like appearance
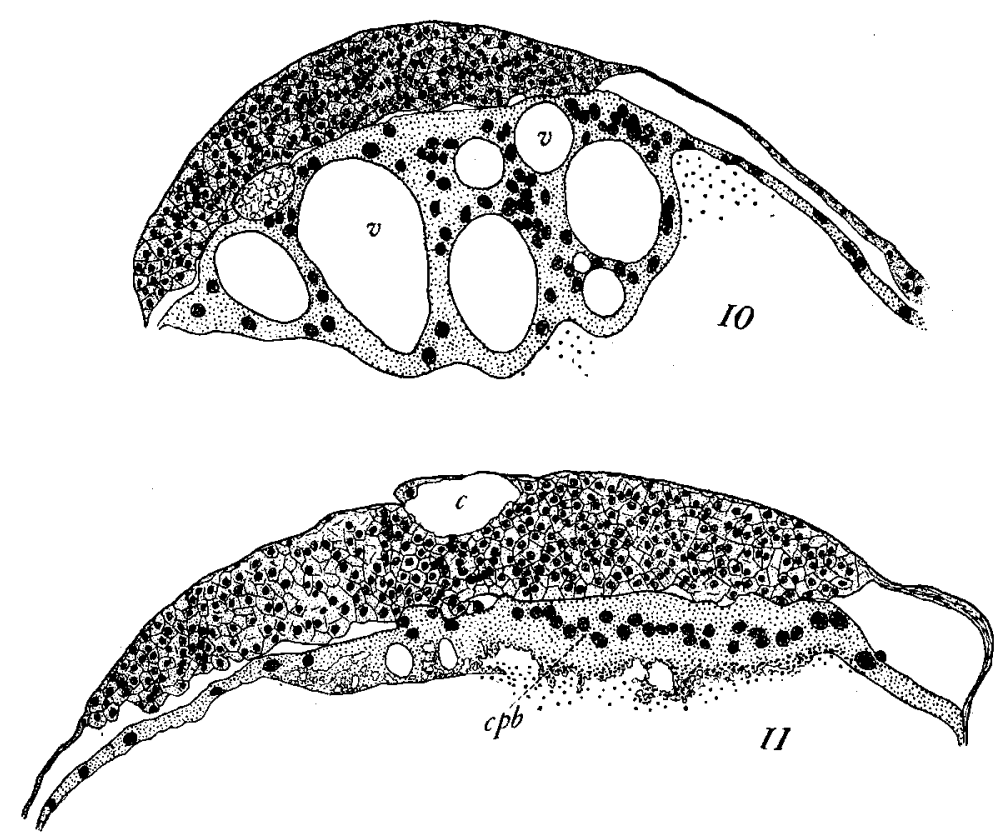

Fig. Io A section of the embryonic shield from an egg thirty hours old in a $\frac{3}{4} \mathrm{~m}$ sea-water solution of $\mathrm{KCl}$, showing huge vacuoles $v$ in the periblast beneath the shield. $\times 58 \frac{1}{3}$ diameters.

Fig. I I A section of the blastoderm of an egg thirty-one hours old that had spent the first twentythree hours after fertilization in a $\frac{1}{12} \mathrm{~m} \mathrm{MnCl}_{2}$ solution. The central periblast, $c p b$ shows much thickened, with many large nuclei accumulated in this region. $c$, Cavity in the blastoderm. $\times 5^{8 \frac{1}{4}}$ diameters.

seen in living eggs. The embryos are always much dwarfed and pale. The heart never contracts although the embryo may remain alive for as long a period as two weeks. The pericardium is often puffed out and is unusually prominent, as also occurs in some other solutions, as shown in Fig. I2, $p c$ for an embryo from a mixture of $\mathrm{MgCl}_{2}$ and $\mathrm{NaCl}$. 
Eggs that remained as long as thirty hours in $\frac{1}{2} \mathrm{~m}$ distilled water solutions of $\mathrm{KCl}$ would recover if placed in sea-water. Other eggs were left for three days in $\mathrm{KCl} \frac{3}{8} \mathrm{~m}$ distilled water solutions, and afterward recovered, the heart beginning to beat, etc., when returned to sea-water. Normal embryos several days old were very readily killed if subjected to even weak solutions of $\mathrm{KCl}$; their heart's action being stopped. It thus seems as though an embryo may live and develop without its heart ever having contracted, but if it had once begun to contract any cause that may stop this contraction proves fatal. My results then in a general way agree with Loeb's observations though I should take exception to his statement that the circulatory system develops normally

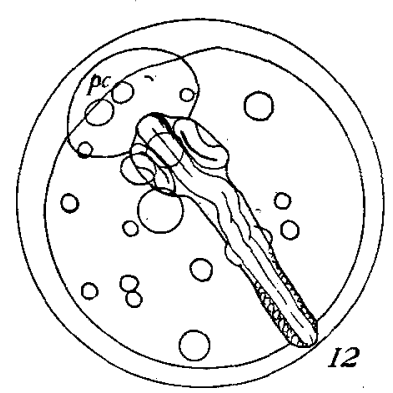

Fig. 12 An embryo from a mixed solution of $\mathrm{MgCl}_{2} \frac{1}{5} \mathrm{~m}+\mathrm{NaCl} \frac{1}{5} \mathrm{~m}$ when forty-three hours old, showing єwollen, $p c$, pericardium. even though the blood does not circulate. The major parts of the system do seem to develop but by no means normally, the heart being small and weak and it is often only a straight tube with the balloon-like pericardium surrounding it. Many clots of red corpuscles are noted in several of the sinuses. The above facts are also of interest in connection with Howell's analysis of the inhibitory action of the vagus nerve on the heart beat as being due to the liberation of $\mathrm{K}$-ions about the nerve endings.

A mixture of $\mathrm{a} \frac{1}{2} \mathrm{~m} \mathrm{KCl}$ and a molecular $\mathrm{NaCl}$ solution was prepared with $60 \mathrm{cc}$. of the former to Io cc. of the latter. This mixture showed the same general effect on the eggs as the simple $\mathrm{KCl}$ solution; the blastoderm bulged up slightly and the yolks were shrunken. Many embryos, however, seemed stronger and better developed with more pigmentation and with larger red blood clots. Some of these embryos were placed in sea-water when seven days old but failed to recover.

$\mathrm{A} \mathrm{CaCl}_{2} \frac{1}{5} \mathrm{~m}$ solution in distilled water proved highly toxic. The blastoderms flattened down, the cells apparently spreading unusually far apart. The eggs died within about twenty-four 
hours. Eggs that were subjected to $\frac{1}{8} \mathrm{~m} \mathrm{CaCl}_{2}$ one hour after fertilization were almost all dead within four hours, the living ones were abnormal, and all died after twenty-four hours. This result further illustrates the readiness with which the egg membrane is penetrated during the first few hours after fertilization. A mixture of 60 cc. $\frac{1}{5} \mathrm{~m} \mathrm{CaCl}_{2}$ and Io cc. $1.0 \mathrm{~m} \mathrm{NaCl}$ proved equally as fatal as the $\mathrm{CaCl}_{2}$ alone had done, neither of the cations seem to exert an anti-toxic action toward the other.

Solutions of $\mathrm{NH}_{4} \mathrm{Cl}$ in distilled water of concentrations $\frac{1}{10} \mathrm{~m}$, $\frac{1}{7} \mathrm{~m}, \frac{1}{3} \mathrm{~m}, \frac{1}{4} \mathrm{~m}, \frac{1}{3} \mathrm{~m}$ and $\frac{1}{2} \mathrm{~m}$ were used; a molecular solution of $\mathrm{NH}_{4} \mathrm{Cl}$ is equivalent to about a 5.05 per cent solution. Sea-water solutions of $\frac{1}{3} \mathrm{~m}, \frac{1}{2} \mathrm{~m}$ and $\frac{3}{4} \mathrm{~m}$ were also employed. These solutions seemed to cause the yolk to shrink slightly, the blastoderm to thicken so that on examining the living eggs one would think that the segmentation cavity was abnormally large as it is in the lithium embryos. On studying sections of these, it was found that the cells are loosely connected, making the blastoderm unusually thick so that it projects down into the yolk. The segmentation cavity is, therefore, not abnormally large as in the lithium embryos. Many of the eggs die at various stages. The rate of development is retarded and the blastopore is slow to close. Many of the embryos are short with their tail ending abruptly. In some embryos the heart beats slowly and the circulation is sluggish; in others there is no pulsation at all, and still others in the same solution may show a very good circulation. Embryos lived as long as eighteen days in such solutions but failed to hatch.

Such short embryos as those above described seem to result from any cause that retards development and prevents the normal down-growth of the germ-ring. When such embryos were removed from $\frac{1}{2} \mathrm{~m} \mathrm{NH} \mathrm{NH}_{4} \mathrm{Cl}$ solutions when forty-three hours old and placed in sea-water, they recovered in one day and hatched when fourteen days old. The embryos in $\mathrm{NH}_{4} \mathrm{Cl}$ are always dwarfed, with poor circulation, lightly colored blood, and sparse pigmentation, having a pale appearance. The sea-water solutions of $\mathrm{NH}_{4} \mathrm{Cl}$ were much less toxic than the distilled water ones.

Mixtures of $\mathrm{NH}_{4} \mathrm{Cl} \frac{1}{5} \mathrm{~m}+\mathrm{MnCl}_{2} \frac{1}{2} \frac{\mathrm{m}}{2}, \mathrm{NH}_{4} \mathrm{Cl} \frac{1}{4} \mathrm{~m}+$ $\mathrm{MnCl}_{2} \frac{1}{25} \mathrm{~m}$ and $\mathrm{NH}_{4} \mathrm{Cl} \frac{1}{7} \mathrm{~m}+\mathrm{MnCl}_{2} \frac{1}{20} \mathrm{~m}$ were tried. The 
eggs lived better in these solutions than in either the $\mathrm{NH}_{4} \mathrm{Cl}$ or the $\mathrm{MnCl}_{2}$. The first twenty-four hours of development is almost normal though some eggs die, the rate of development after this period becomes retarded, the embryos have swollen pericardia in some cases, and are pale and small. Some of them continued to live in these solutions for fifteen days but were far from the hatching stage at this time. The weaker toxicity of these mixtures when compared with the action of the salts used singly may be due as Loeb ('O2) has claimed, to an anti-toxic effect of one ion on the other. The mixtures with less $\mathrm{NH}_{4} \mathrm{Cl}$ were always less active. Loeb found the bivalent cations to show an anti-toxic action toward the monovalent ones.

$\mathrm{MnCl}_{2}$ solutions were used of the strengths $\frac{1}{25} \mathrm{~m}, \frac{1}{16} \mathrm{~m}$, and $\frac{1}{12} \mathrm{~m}$ in distilled water; and $\frac{1}{16} \mathrm{~m}, \frac{1}{12} \mathrm{~m}$, and $\frac{1}{8} \mathrm{~m}$ in sea-water. Eggs that were subjected to the action of such solutions responded in the following way: Those in the distilled water solutions go normally for several hours, then when -about eighteen or twenty hours old the blastoderm shows a dark central portion when viewed from above, while in side view it shows that the dark area protrudes downward into the yolk. A section of such a blastoderm is seen in Fig. II. The dark area is shown to result from an unusual thickening in the center of the central periblast, $c p b$, and the accumulation at this point of a number of the large periblast nuclei. A slight cavity, $c$, is not uncommon near the surface of the blastoderm. This unusual thickening of the periblast seems to render difficult the subsequent descent of the germ-ring, and development is thus slightly retarded. When about forty hours old many embryos have their germ-rings only one-half over the yolks, and a short embryo is outlined on the embryonic shield. Many of the eggs died in these solutions. The embryos have a feeble pulse and the blood is often clotted in some of the larger vessels. When fifteen days old embryos hatched in the $\frac{1}{25} \mathrm{~m}$ solutions but swam abnormally; one embryo was seen to hatch in a $\frac{1}{16} \mathrm{~m} \mathrm{MnCl}_{2}$ solution but it was entirely unable to swim.

The solutions of $\mathrm{MnCl}_{2}$ in sea-water formed slight precipitates and the results are thus no doubt vitiated to some extent, nevertheless the dark central portion of the blastoderm always showed. 
Short embryos with open blastopores were formed in many cases. The heart was weak and tubular with feeble contractions and was surrounded by a swollen pericardium. One embryo when eleven and one-half days old hatched in a $\frac{1}{2} \bar{s} \mathrm{~m}$ solution, but was unable to swim. In many of these embryos no heart beat could be detected and the yolks were badly shrunken. In one case a one-eyed embryo was noted, this is mentioned on account of the tendency of magnesium salts to produce such a condition, but the eye structures of this embryo were very imperfect and no lens was present, this condition will be found to differ entirely from that described below as caused by the action of $\mathrm{MgCl}_{2}$.

Eggs were subjected to $\mathrm{MgCl}_{2}$ solutions of the following strengths $\frac{1}{70} \mathrm{~m}, \frac{1}{8} \mathrm{~m}, \frac{1}{5} \mathrm{~m}$, and $\frac{1}{4} \mathrm{~m}$ in distilled water, and $0.238 \mathrm{~m}$, $0.25 \mathrm{~m}, 0.286 \mathrm{~m}, 0.33 \mathrm{~m}$ and $0.5 \mathrm{~m}$ in sea-water; a molecular solution of $\mathrm{MgCl}_{2} \cdot 6 \mathrm{H}_{2} \mathrm{O}$ being equivalent to about a 20.3 per cent solution. The early development in all of these solutions is strikingly normal considering the large death rate which occurs during these stages. The salt seems especially toxic to the early embryo. At seventyfour hours some embryos are well formed, though behind the control in their development, and the blood circulation is slow in some while others have a quick heart action. When ten days old all are weak and smaller than the control, the blood flow is slow and spasmodic; in some embryos the circulation has ceased and the blood is collected in the sinus and heart and appears as a red streak in front of the head. Many of the livelier embryos wave their pectoral fins.

In the $\frac{1}{8} \mathrm{~m}$ and $\frac{1}{5} \mathrm{~m}$ distilled water solutions many embryos hatch when about fifteen days old, though they swim abnormally on account of their bodies being twisted. The sea-water solutions cause the yolks to shrink and in these the embryos are also small with sluggish circulations. Although kept alive for twenty-four days none of the eggs in the sea-water solutions would hatch.

The conditions cited above are general and occurred also in a number of different salt solutions, but the condition which may now be considered seems peculiarly characteristic of the Mg salt. In the $\frac{1}{3} \mathrm{~m}$ sea-water solutions one-eyed embryos occurred with surprising regularity in $5^{\circ}$ per cent of the eggs. This experiment 
was repeated three times and each time it so happened that exactly one-half of the embryos had only one eye. These cyclopean fish were rather abnormally shaped though they were able to twist about and wave their pectoral fins vigorously. The other embryos were apparently normal in all particulars, the magnesium seeming not to have affected them.

In sections the one-eyed condition was found to result from the union or fusion of the Anlagen of the two optic vesicles. Cases were found illustrating various degrees in this fusion, it seemed as though the optic vesicles were formed too far forward and ventral and thus their antero-ventro-median surfaces fused. This condition results in one large optic vesicle which in all cases gives more or less evidence of its fused or double nature.

As a rule but a single lens is formed, the size of which depends upon the size of the optic cup or more exactly upon the size of the ectodermal area influenced by the optic cup to form a lens. This lens formation is interesting in connection with the results of the experimental work of Lewis ('O4) and others on the lens development in Amphibians. I ('o7) have entered into a more detailed discussion of this subject elsewhere.

The lens was found to show a double or fused structure in one case out of the ten embryos that were sectioned; the other portions of this eye were also more distinctly double than was usually the case. This condition represents the last step in the fusion of the two eyes, slightly greater fusion would result in a single eye.

With no other solution has such a condition as the above been procured, and its abundant occurrence in sea-water solutions of $\mathrm{MgCl}_{2}$ strongly indicates that this one-eyed condition is characteristic of the action of such solutions on the developing Fundulus embryo.

Solutions of $\mathrm{MgCl}_{2} \frac{1}{10} \mathrm{~m}+\mathrm{NaCl} \frac{1}{5} \mathrm{~m}$ in distilled water, and $\mathrm{MgCl}_{2} \frac{1}{5} \mathrm{~m}+\mathrm{NaCl} \frac{1}{5} \mathrm{~m}$ in sea-water were tried on the eggs with the results following:

The distilled water mixture produced no effect on the development, nor do such strengths of the two salts employed separately.

The sea-water mixture contained twice as much $\mathrm{MgCl}_{2}$ as the distilled water one. The results are instructive. When eighteen 
hours old the blastoderms were raised up prominently on the yolks. Many eggs died during early cleavage, and altogether the eggs are decidedly abnormal. Neither of these salts acting alone would give such an effect. When forty-two hours old the yolks are shrunken and all of the embryos have a balloon-like pericardium in front of the head, Fig. I2, pc. Later, the circulation often becomes feeble. This occurs also in simple $\mathrm{MgCl}_{2}$ solutions.

When nine days old the embryos are small and the yolks shrunken. All steps of the fusion of the two eyes into one are shown. This condition makes it certain that the magnesium of the mixture has acted upon the embryos. After fifteen days the eggs are still alive, though small and pale. Thus this double solution is more active than a simple $\mathrm{MgCl}_{2}$ solution and produces magnesium effects with really less magnesium present than is necessary to give a like result when $\mathrm{MgCl}_{2}$ acts alone in sea-water. It was stated above that a strength of $\frac{1}{4} \mathrm{~m} \mathrm{MgCl}_{2}$ in sea-water was the weakest solution that caused the one-eyed embryo. The fact that in the mixture a $\frac{1}{5} \mathrm{~m} \mathrm{MgCl}_{2}$ sea-water solution gives a like effect may be due to the additional osmotic pressure exerted by the $\mathrm{NaCl}$ present as has been suggested by Morgan ('o6), to explain similar phenomena in the action of salt solutions on frog eggs. It may also be suggested that the $\mathrm{Mg}$ ions act against the $\mathrm{Ca}$ ions of the sea-water and thus permit the $\mathrm{Na}$ ions to become more active, but this explanation will certainly not apply here, since the embryos show characteristic magnesium effects.

Eggs were subjected to distilled water solutions of $\mathrm{NaCl} \frac{1}{5} \mathrm{~m}$, $\frac{1}{4} \mathrm{~m}$ and $\frac{3}{3} \mathrm{~m}$. During the first day of development many died in most of these solutions. When the eggs were forty-eight hours old the $\frac{3}{8} \mathrm{~m}$ solution contained many dead eggs, although the few still alive were almost normal in appearance. This solution contains only 2.I9 per cent $\mathrm{NaCl}$ which is less than the amount in normal sea-water yet it is obviously toxic to these eggs. It is evident that other salts present in the sea-water counteract this toxic effect of $\mathrm{NaCl}$. When fourteen days old all of the living embryos appear normal. The $\frac{3}{8} \mathrm{~m}$ solution contained one hatched embryo which had a slow pulse and feeble fin movements, it lay at rest on one side but moved if pricked with a needle. In the $\frac{1}{4} \mathrm{~m}$ solution of $\mathrm{NaCl}$ 
more embryos had hatched than in the control though all of these fish swim with a jerky motion often moving in a spiral course or even turning somersaults in the water. The salt seems to act either upon the nerves or muscle fibers of the embryo causing the nervous twitching or jumping movements. The pectoral fins seem to lack their usual coördination. This condition is not induced by the absence of some constituent of the sea-water since embryos hatched in distilled water swim normally. The result is then undoubtedly due to the action of the $\mathrm{NaCl}$. The embryos die within one or two days after hatching with their bodies peculiarly curled or twisted. Jenkinson ('o6) has lately recorded a similar twisting and inability to swim for newly hatched tadpoles in $\mathrm{NaCl}$ solutions.

Sea-water solutions of $\frac{3}{8} \mathrm{~m}, \frac{5}{8} \mathrm{~m}$ and molecular concentrations of $\mathrm{NaCl}$ showed only a tendency to shrink the yolk. The development progressed almost normally and only a few eggs died. On their shrunken yolks the embryos when six days old were small and behind the control in their development. At fourteen days the embryos hatched in the $\frac{3}{8} \mathrm{~m}$ and $\frac{5}{8} \mathrm{~m}$ solutions, those in the weaker solution swam normally while those in the stronger showed the same jerky motions described above. On comparing these effects with those in the distilled water solutions it is reasonable to suppose that some constituent of the sea-water is capable of counteracting the effect of $\mathrm{NaCl}$ up to a given point ${ }^{7}$ but when an excessive amount of the salt is present its action is not entirely checked.

Eggs lived for twenty-four days in a healthy condition in the molecular $\mathrm{NaCl}$ solution although none of them hatched. Loeb kept eggs as long as five weeks in a $\mathrm{NaCl}$ solution in sea-water without hatching.

Embryos three days old were subjected to a double molecular

\footnotetext{
7 In 1902 Loeb found that Fundulus embryos would not develop in a solution of $\mathrm{NaCl}$ in distilled water equivalent to the concentration of $\mathrm{NaCl}$ in the sea; he then added a trace of calcium salt and found development to be normal. After a number of experiments the conclusion was reached that the salts of monovalent cations with monovalent anions exert a toxic effect at certain concentrations. This toxic effect could be annihilated through the addition of a small amount of a salt having a bivalent cation or by a still smaller amount of one having a trivalent cation. In other words, the antitoxic effects of cations vary directly as the valence of the elements. It was also found that mono-, bi-, or trivalent anions were all unable tu produce a like effect.
} 
solution of $\mathrm{NaCl}$ in sea-water and they continued to develop in an apparently normal fashion but with their yolks shrunken. Loeb ('94) had found that embryos three or four days old might be placed into a $27^{\frac{1}{2}}$ per cent sea-water solution of $\mathrm{NaCl}$ and continue normal development. None of these embryos, however, will hatch.

In several of the $\mathrm{NaCl}$ solutions I found embryos that lacked all skin pigmentation thus appearing almost white, these were not true albinos, however, since their eyes showed pigment. Such pale embryos hatched when returned to sea-water.

After a consideration of the foregoing results one must admit, it seems to me, as probable that some of the elements exert a specific stimulus on the fish embryo and cause it to develop in a characteristic manner. $\mathrm{LiCl}, \mathrm{KCl}, \mathrm{MnCl}_{2}$ and $\mathrm{MgCl}_{2}$ seem to induce rather constant and definite effects or types of embryos. The form of the embryo seems to be influenced by external factors in development as well as by internal ones; in other words, the chemical environment of an egg is important in determining the final resultant of the factors in inheritance.

It may be suggested as a probability that every element that forms a chemical union with the germ substance produces on the developing egg through its action definite anatomical and physiological effects, which of course will vary in different kinds of eggs. Thus since the normal form of an animal may be altered in a definite way by certain chemical actions of the elements, we may assume that the specific nature of any animal is a product of the chemical composition of the egg cell from which it sprang.

THE ACTION OF MIXTURES OF SALTS IN SOLUTION: THE CHEMICAL VERSUS THE OSMOTIC EFFECTS

The following experiments were conducted in order to determine whether or not by increasing the osmotic pressure of the solution through the addition of a chemically indifferent substance, such as sugar, the chemical action of salts might be augmented. In other words, will eggs become more susceptible to the chemical action of a weak salt solution if the osmotic pressure of this solution be increased? Morgan ('o6) has performed similar experiments 
with frog's eggs and concludes that in order to be effective the two solutions together must exert a higher pressure than the one producing its effect at the lower limit but less than for the other that produces its effect at a higher pressure. These osmotic pressure effects are somewhat contri dictory as I have above pointed out in mentioning Morgan's results in which he finds the upper limit of $\mathrm{NaCl}$ to be about 2 per cent with a pressure of $13.6 \mathrm{I}$ atmospheres, while a like fatal limit for sugar was found to exert a pressure of only 8.376 atmospheres. It is also recalled that I described above a like contradiction in comparing the pressures of fatal sea-water solutions of sugar with similar solutions of $\mathrm{MgCl}_{2}$. As there stated, this contradiction is possibly due to the fact that the cane sugar in solution becomes inverted and thus the actual pressure is really double that calculated.

In working with Fundulus eggs, as has been already pointed out, the experimenter has the advantage of being able to keep them alive in solutions which exert pressures both above and below that to which the eggs are normally accustomed. This fact has been of especial value in analyzing the results of the following experiments. To anticipate what is to follow it may be stated that on adding certain percentages of sugar to a distilled water salt-solution, the action of the salt was increased although the total pressure of the solution was less than the osmotic pressure of ordinary sea-water. Such a result may probably be due to the action which would take place if the sugar became inverted in the solution.

The following distilled water solutions of $\mathrm{LiCl}+$ sugar were employed in one experiment, $\mathrm{LiCl} 0.128 \mathrm{~m}, 0.096 \mathrm{~m}, 0.064 \mathrm{~m}$ and $0.032 \mathrm{~m}$ with $0.44 \mathrm{~m}$ of cane sugar in each. All of these solutions exert an osmotic pressure less than that of sea-water, except possibly the first which has an almost equal pressure. After nineteen hours the eggs in $\mathrm{LiCl} 0.128 \mathrm{~m}+0.44 \mathrm{~m}$ sugar had polar caps with "bubbles" beneath and many were dead, those in $\mathrm{LiCl}$ $0.096 \mathrm{~m}+0.44 \mathrm{~m}$ sugar were in about the same condition. $\mathrm{LiCl}$ $0.064 \mathrm{~m}+0.44 \mathrm{~m}$ sugar had also produced polar caps and no germrings were formed, $\mathrm{LiCl} 0.032 \mathrm{~m}+0.44 \mathrm{~m}$ sugar had caused half of the embryos in it to die, while the living ones had formed abnormal germ-rings. Eggs in a solution of $\mathrm{LiCl} 0.032 \mathrm{~m}$ are scarcely 
if at all affected at this time, and those in $0.44 \mathrm{~m}$ sugar are normal. The eggs continue to show these graded abnormalities in the different solutions and when sixty-eight hours old were as follows: All were dead in the three stronger mixtures, and a few short embryos had been formed and were still alive in the $\mathrm{LiCl} 0.032 \mathrm{~m}$ $+0.44 \mathrm{~m}$ sugar. In $\mathrm{LiCl} 0.128 \mathrm{~m}$ at sixty-eight hours many were dead but a good number of short embryos were present; in the $\mathrm{LiCl} 0.032 \mathrm{~m} 20$ per cent of the embryos were almost normal. In the $0.44 \mathrm{~m}$ sugar solution the embryos were normal. The result shows that sugar augments the action of the $\mathrm{LiCl}$ although the pressure of the mixed solution is less than that in which the eggs usually live. This conclusion seems to me correct for now I realize the improbability that the sugar may have inverted which would thus have exerted twice the pressure supposed; if this were true then all of the solutions would have a pressure higher than that of the sea-water, though still not high enough in themselves to cause any of the above effects as will be readily seen by comparing the pressures of sea-water solutions in which the eggs develop normally.

A reverse experiment was conducted in which the amount of $\mathrm{LiCl}$ present in the solution was constant while varying amounts of sugar were added. $\mathrm{LiCl} 0.032 \mathrm{~m}$ was mixed with $0.293 \mathrm{~m}$, $0.44 \mathrm{~m}, 0.586 \mathrm{~m}$ and $0.88 \mathrm{~m}$ sugar, and $\mathrm{LiCl} 0.016 \mathrm{~m}$ with 0.293 $\mathrm{m}, 0.44 \mathrm{~m}, 0.586 \mathrm{~m}, 0.88 \mathrm{~m}$ and $\mathrm{I} .253 \mathrm{~m}$ sugar. The results of these experiments showed as one would expect from the above that the injurious action of the solutions increased with the amount of sugar present, and moreover the activity of the mixture was always stronger than that of either constituent when used alone. The last point is well illustrated by eggs of forty-eight hours in the solution of $\mathrm{LiCl} 0.032 \mathrm{~m}+$ sugar $0.586 \mathrm{~m}$. All the eggs in this solution have the blastoderm in the form of a ball on the upper pole, only a few are still alive and in these the large bubble-like segmentation cavity is present. The osmotic pressure of this mixture is lower than that of sea-water provided that the sugar has not inverted. At this time, forty-eight hours, eggs in $0.586 \mathrm{~m}$ sugar solution are all normal, and those in $0.032 \mathrm{~m} \mathrm{LiCl}$ almost all have their germ-rings three-quarters of the way over the yolks with short embryos formed; some, however, have the germ-ring only onequarter or one-third of the way down. 
Mixed solutions of $\mathrm{LiCl}$ and sugar were also prepared in seawater. A $0.293 \mathrm{~m}$ solution of sugar was added to $0.33^{6} \mathrm{~m}, 0.256 \mathrm{~m}$ and $0.192 \mathrm{~m}$ solutions of $\mathrm{LiCl}$. The general results agree with those described above for the distilled water solutions, although the contrast between the simple $\mathrm{LiCl}$ solutions, and the mixtures was not so sharp. Figs. I 3 to 17 of eggs when twenty hours old serve to indicate very well the conditions caused by the solutions at this period. Fig. I 3 shows the appearance of the majority of eggs in $\mathrm{LiCl} 0.256 \mathrm{~m}+$ sugar $0.293 \mathrm{~m}$. Fig. I4 shows the egg nearest normal in the same solution. Fig. 15 indicates the stage that the large majority of eggs in $\mathrm{LiCl} 0.256$ without the sugar have reached at this time. A marked difference exists between this embryo and those in the mixture. Fig. I6 is the most abnormal one in the $\mathrm{LiCl} 0.25^{6} \mathrm{~m}$ and $\mathrm{Fig}$. I 7 shows a control egg at this age.

Eggs were subjected to the following distilled water mixtures of $\mathrm{NH}_{4} \mathrm{Cl}$ and sugar, $\mathrm{NH}_{4} \mathrm{Cl} \frac{1}{5} \mathrm{~m}, \frac{1}{7} \mathrm{~m}$, and $\frac{1}{10} \mathrm{~m}+0.44 \mathrm{~m}$ sugar. The development of the eggs in these different strength mixtures was as we would expect from the result shown above. Those in the $\mathrm{NH}_{4} \mathrm{Cl} \frac{1}{5} \mathrm{~m}+$ sugar $0.44 \mathrm{~m}$ were all dead within nineteen hours with their blastoderms in the form of balls of cells on the upper pole of the egg. At this time some of those in $\mathrm{NH}_{4} \mathrm{Cl} \frac{1}{7} \mathrm{~m}$ + sugar $0.44 \mathrm{~m}$ had the germ-ring one-quarter way down the yolk, the majority, however, showed the blastoderms as polar balls which had not flattened down; many were dead. The weakest solution produced fewer abnormalities. The eggs in the $0.44 \mathrm{~m}$ solution of sugar were normal at this time, nineteen hours, and those in $\mathrm{NH}_{4} \mathrm{Cl} \frac{1}{3} \mathrm{~m}$ had thirteen normal and seven dead.

When forty-three hours old all of those in $\mathrm{NH}_{4} \mathrm{Cl} \frac{1}{7} \mathrm{~m}+$ sugar $0.44 \mathrm{~m}$ were dead, no embryos having been formed. Those in the weak solution $\mathrm{NH}_{4} \mathrm{Cl}_{\frac{1}{1} \delta} \mathrm{m}+$ sugar $0.44 \mathrm{~m}$ were also dead at this time. Both of these solutions exert an osmotic pressure less than that of sea-water. After forty-three hours eggs in $\mathrm{NH}_{4} \mathrm{Cl} \frac{1}{7} \mathrm{~m}$ were almost normal, and their condition in $\mathrm{NH}_{4} \mathrm{Cl} \frac{1}{10} \mathrm{~m}$ was the same, while those in the $0.44 \mathrm{~m}$ sugar were well up with the control. Thus again we see that the mixture exerts a far greater influence on development than either constituent acting alone is 
capable of producing. It appears in this instance rather illogical to state that the extra pressure induced by the addition of sugar to the solutions of $\mathrm{NH}_{4} \mathrm{Cl}$ caused this salt's action to become more pronounced upon the eggs, for as mentioned before the pressure of these mixtures is often below the usual pressure in which the eggs live, and from the experiment cited below we shall find that the

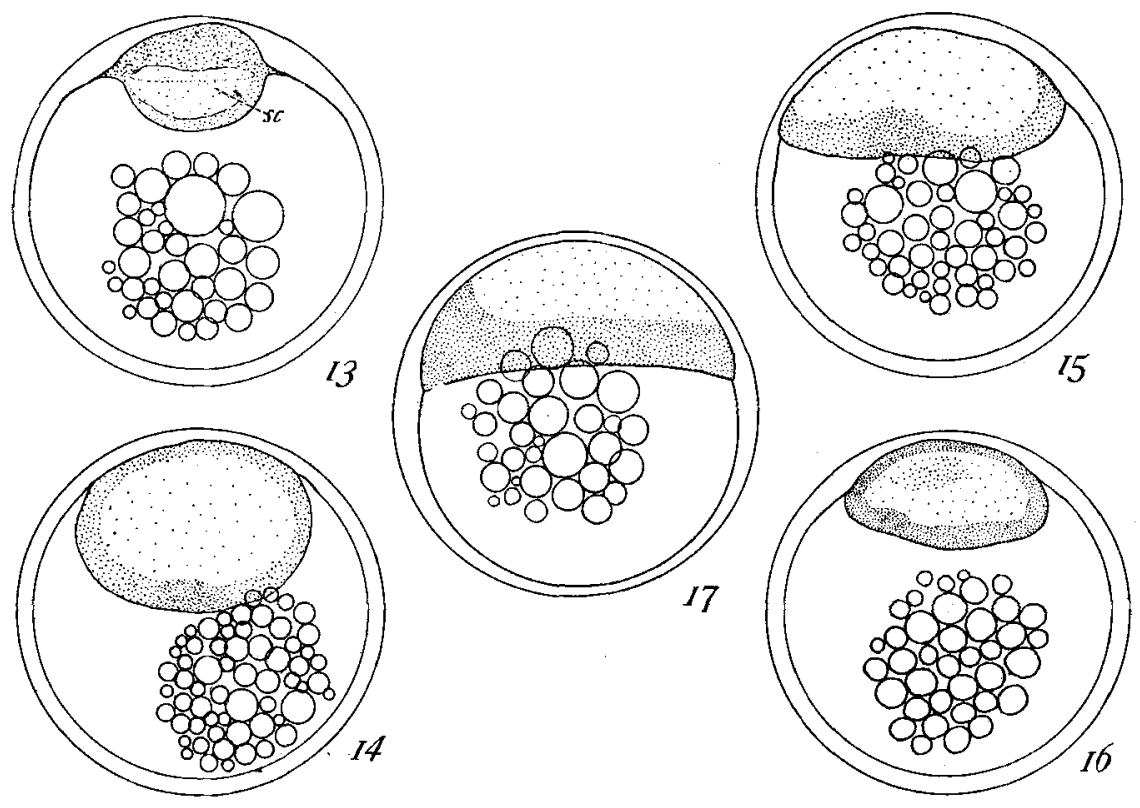

Fig. 13 An embryo when twenty hours old in $\mathrm{LiCl} 0.256 \mathrm{~m}+$ sugar $0.293 \mathrm{~m}$, the majority of eggs in this solution are in a similar condition. sc, segmentation cavity.

Fig. I4 The least affected egg in the above solution.

Fig. 15 The majority of the eggs in simple $\mathrm{LiCl} 0.256 \mathrm{~m}$ solution show this condition.

Fig. 16 The most abnormal egg in the $\mathrm{LiCl} 0.256 \mathrm{~m}$ solution at this time.

Fig. 17 A control egg when twenty hours old. All $\times 17 \frac{1}{4}$ diameters.

addition of sugar to sea-water solutions of $\mathrm{NH}_{4} \mathrm{Cl}$, which are of course hypertonic, furnish rather indifferent results. One might argue on the other hand that salts of the sea counteract the effects of the $\mathrm{NH}_{4}$ ion, but even if this does occur the high pressure does not particularly injure the eggs, and we are still in the dark concerning the question why the distilled water solutions of $\mathrm{NH}_{4} \mathrm{Cl}$ 
act more violently in the presence of sugar unless it be due to some action which might take place when the sugar molecules split if they become inverted in the solutions. Eggs are necessarily very delicate chemical indicators and it may be that an action hitherto undetected might be shown by them. Furthermore, Fundulus eggs are exceptionally adapted to the study of such questions as they are not necessarily subjected to abnormally high pressure in experimentation.

Sea-water mixtures of $\mathrm{NH}_{4} \mathrm{Cl} \frac{1}{3} \mathrm{~m}, \frac{1}{5} \mathrm{~m}$, and $\frac{2}{13} \mathrm{~m}+$ sugar $0.293 \mathrm{~m}$ were used with rather indifferent results. In each of the three mixtures the yolks were slightly shrunken and in the two stronger a small per cent of the eggs always died during the first day of development, but from this time until nine or ten days old they developed in a normal manner though somewhat slower than the control. When fifteen days old in $\mathrm{NH}_{4} \mathrm{Cl}_{3} \frac{1}{\mathrm{~m}}+$ sugar $0.293 \mathrm{~m}$ 95 per cent of the eggs were dead and the few embryos alive were small with feeble pulse. They appeared as embryos should when seven or eight days old. In $\mathrm{NH}_{4} \mathrm{Cl} \frac{1}{5} \mathrm{~m}+$ sugar $0.293 \mathrm{~m}$ $5^{\circ}$ per cent were dead and the others were small and otherwise like those described above. The eggs in the $\mathrm{NH}_{4} \mathrm{Cl} \frac{2}{15}+$ sugar $0.293 \mathrm{~m}$ were all normal except for the small size of the yolks. None had hatched. In the $0.293 \mathrm{~m}$ sugar solution all had a normal development; and in the sea-water solutions of $\mathrm{NH}_{1} \mathrm{Cl} \frac{1}{5} \mathrm{~m}$ and ${ }_{12}^{2} \mathrm{~m}$ development was almost normal except for the contraction of the yolks. The embryos were a little retarded in development and none of them hatched. These results lead also to the same general conclusion, that the mixture acts more violently than would either constituent acting alone, although the difference in action here is not great.

\section{SUMMARY AND CONCLUSIONS}

I The membrane of the eggs of Fundulus heteroclitus is readily permeable to salts in solution as is shown in embryos a few days old by the fact that $\mathrm{KCl}$ will stop their heart action within a few moments.

During the early stages the membrane is also easily penetrated since eggs subjected to the action of strong solutions of $\mathrm{LiCl}$ for 
one or two hours do not recover from the effects of this treatment after being returned to sea-water. Many other facts go to show the readiness with which this membrane is permeated.

2 Fundulus eggs develop normally, although at a somewhat faster rate, when kept on moist plates entirely out of water. The embryos developed out of water are unable to hatch while on the moist plates, but if at any time after the control has begun hatching some of the eggs are immersed in sea-water they will soon begin hatching, commencing usually in about ten minutes after being in the water and all coming out very promptly. On hatching the embryos show a positively heliotropic and a negatively geotropic reaction.

Embryos were kept for thirty-three days, or twenty days after the control had begun hatching, on these moist plates without beginning to hatch. The fish within the egg membrane grows in length and absorbs its yolk at about the same rate as hatched ones do. They finally die of starvation after having assimilated all of their yolk, being still confined within the egg membrane.

3 Fundulus eggs are not entirely immune to osmotic effects though it has often been stated that they are. In weak cane sugar solutions the yolks were observed to swell, this has never been seen even in eggs developing in distilled water and may probably be due to some change taking place in the sugar after it has permeated the egg membrane. In concentrated sugar solutions the yolk shrinks in a somewhat definite manner. A I.53 m distilled water solution of cane sugar killed the eggs within twenty-three hours. The osmotic pressure of such a solution is calculated to be 34.278 atmospheres or about twelve atmospheres more than that of sea-water. Some salt solutions which exert even a greater pressure do not kill the eggs. This contradiction might be explained if the cane sugar becomes inverted in the solutions but from the evidence at hand this interpretation seems improbable. There may possibly be an action of the new substances resulting from the inversion of the cane sugar molecule which is also injurious to the eggs.

Eggs hatch in $0.166 \mathrm{~m}$ solutions of sugar in sea-water. On comparing the effects of sea-water solutions of sugar with distilled water solutions it was found that a pressure more than double as 
high in sea-water produced a much less marked effect. Such ot servations seem to indicate that the eggs were less resistant to chemicals when treated in fresh water, due possibly to a slightly weakened condition when out of their usual medium. The fresh water solutions showed a strong tendency to become acid and a fungus-like growth was often present (see footnote, p. 178). It will also be recalled that the acid condition of the medium would in itself be injurious to the eggs.

4 Eggs that were subjected to the action of $\mathrm{LiCl}, \mathrm{LiNO}_{3}$ and $\mathrm{Li}_{2} \mathrm{SO}_{4}$ were all affected in a similar manner, seeming to indicate that the cation common to the three salts was the active principle concerned. Of the large number of other salt solutions employed none of the metallic ions gave the same constant abnormalities which lithium induced. The lithium larva of Fundulus is as definite and well marked as those recorded by Gurwitsch and Morgan for the frog.

5 a It was found, as Loeb had already shown, that this egg will develop in solutions of $\mathrm{KCl}$ and live for several weeks without developing a heart beat. Loeb's statement that the circulatory system develops normally is incorrect, since the heart itself is abnormal, the pericardium is often greatly swollen, and other portions of the system are defective. Although eggs will live and develop in these solutions if placed in them soon after fertilization an embryo several days old will be killed in a few moments if treated in a like manner. Thus when the heart's action has once become established the embryo can no longer withstand the action of $\mathrm{KCl}$.

$b$ The effects of $\mathrm{NH}_{4} \mathrm{Cl}$ on these eggs were rather general, development was retarded, the blastopore was slow closing and many short embryos resulted. The circulation was poor. Some lived in these solutions for eighteen days though none hatched.

In mixtures of $\mathrm{NH}_{4} \mathrm{Cl}$ with $\mathrm{MnCl}_{2}$ eggs were less affected than in solutions of either of these salts used singly. This fact may be due to the antitoxic action of one cation on another as Loeb has claimed to take place.

c $\mathrm{MnCl}_{2}$ solutions prepared in fresh water caused a thickening or concentration of the central periblast in early stages, development was retarded, and the embryo had a feeble pulse. Some of 
the embryos in the weaker solutions hatched but swam abnormally. Solutions of $\mathrm{MnCl}_{2}$ in sea-water induced similar effects.

$d$ Sea-water solutions of $\mathrm{MgCl}_{2}$ caused the embryos to form one large single and almost terminal eye. This single eye results from an early fusion of the two optic vesicles. The optic cup is, therefore, abnormally large and the size of the lens in such eyes varies directly with the size of the optic cup. This condition is to be compared with that known in human monsters as Cyclopia. $\mathrm{MgCl}_{2}$ when mixed with $\mathrm{NaCl}$ also caused this abnormality.

$e$ Eggs that were treated with $\mathrm{NaCl}$ solutions showed no abnormalities during their early development. In the weaker solutions many embryos hatched but were unable to. swim in a normal fashion. The $\mathrm{NaCl}$ affects either the nerve or muscle substance of these fish causing them to swim with jerky motions, and to fall on one side when at rest. The embryos would live for many weeks without hatching in very strong $\mathrm{NaCl}$ solutions.

6 Mixed solutions of salts and sugar act more violently on these eggs than either constituent would if used alone. Very small doses of a salt will give the effect of a much stronger dose, provided that sugar has been added to the solution. The presence of the sugar thus seems to augment the activity of the salt. This may be due to the additional osmotic pressure that the sugar exerts, but such an explanation is not entirely satisfactory.

Pathological Laboratory

Cornell University Medical College

N , Yorlz City, December I, 1906

LITERATURE CITED

Brown, O. H., 'o3-The Immunity of Fundulus Eggs and Embryos to Electrical Stimulation. Am. Jour. Physiol., ix, pp. I I I-II5.

'05. The Permeability of the Membrane of the Egg of Fundulus Heteroclitus. Am. Journ. Physiol., xiv, pp. 354-358.

Garrey, W. E., '05-The Osmotic Pressure of Sea-water and of the Blood of Marine Animals. Biol. Bull., viii, pp. 257-270.

Gurwrtsch, A., '95-Ueber die Einwirkung des Lithionchlorids auf die Entwickelung des Frosch und Kröteneier (Rana fusca und Bufo vulg.). Anat. Anz., xi, pp. 65-7o. 
Gurwitsch, A., ' 96 -Ueber die formative Wirkung des veränderten chemischen Mediums auf die embryolane Entwickelung. Arch.f. Entw.-Mech., iii, pp. 219-260.

Herbst, C., '92-Experimentelle Untersuchungen über den Einfluss derveränderten chemischen Zusammensetzung des umgebenden Mediums auf die Entwickelung der Thiere. I. Theil. Zeitsh. f. wissensch.Zool., iv, 3 pp. $446-518$.

'93-Experimentelle Untersuchungen. II. Theil. Mittheil. aus der Zool. Station zu Neapel, xi, pp. I36-220.

'96-Experimentelle Untersuchungen. III, IV, V und VI. Theil. Arch. f. Entw.-Mech., ii, pp. 455-5I6.

Howell, W. H., 'o6-Vagus Inhibition of the Heart in its Relation to the Inorganic Salts of the Blood. Am. Jour. Physiol. xv, pp. 280-294.

Jenkinson, J. W., 'o6-On the Effect of Certain Solutions upon the Development of the Frog's Egg. Arch. f. Entw.-Mech. xxi, pp. 367-460.

LEwis, W. H., 'O4-Experimental Studies on the Development of the Eye in Amphibia. I. On the Origen of the Lens. Rana palustris. Am. Jour. Anat., iii, pp. 505-536.

LoEв, J., '92-Investigations in Physiological Morphology. III. Experiments on Cleavage. Jour. Morph., vii, pp. 253-262.

'93-Ueber die Entwicklung von Fischembryonen ohne Kreislauf. Pflüger's Archiv, liv, pp. 525-53.

'94-Ueber die relative Empfindlichkeit von Fischembryonen gegen Sauerstoffmangel und Wasserentziehung in verschiedenen Entwicklungsstadien. Pfüger's Archiv, lv, Pp. 530-54I.

'95-Untersuchungen über die physiologischen Wirkungen des Sauerstoffmangels. Pflüger's Archiv, lxii, pp. 249-294.

'oo-On Ion-proteid Compounds and Their Rôle in the Mechanics of Life Phenomena. I. The Poisonous Character of a Pure $\mathrm{NaCl}$ Solution. Am. Jour. Fhysiol., iii, pp. 327-338.

'o2-The Toxic and the Antitoxic Effects of Ions as a Function of their Valency and Possibly their Electrical Charge. Am. Journ Physiol., vi, pp. 4 II.

'05-Studies in General Physiology. Univ. of Chicago Press.

Mathews, A. P., 'o4-The Relation between Solution Tension, Atomic Volume, and the Physiological Action of the Elements. Am. Jour. Physiol., X, pp. 290-323.

Morgan, T. H., '03-The Relation between Normal and Abnormal Development of the Embryo of the Frog, as Determined by the Effects of Lithium Chlorid in Solution. Arch. f. Entw.-Mech., xvi, pp. 691-712.

'o6-Experiments with Frog's Eggs. Biol. Bull., xi, pp. 71-92. 
Rondeau-Luzeau, 'o2-Action des Chlorures en Dissolution sur le Développement des œufs de Batraciens. Thèses prés. Faculté des Sci. de Paris Univ.

Stockard, C. R., 'o6-The Development of Fundulus Heteroclitus in Solutions of Lithium Chlorid, with Appendix on its Development in Fresh Water. Jour. Exper. Zoöl., iii, pp. 99-r20.

'o7-The Artificial Production of a Single Median Cyclopean Eye in the Fish Embryo by Means of Sea Water Solutions of Magnesium Chlorid. Arch. f. Entw.-Mech. xxiii, pp. 249-258.

Sumner, F. B., 'o6-The Physiological Effects upon Fishes of Changes in the Density and Salinity of Water. Bull. U. S. Bureau Fisheries, xxv, pp. $53^{-108 .}$ 